\title{
The Need for Theatre Arts Education in National Reformation
}

\author{
Rowland U. Aleshi \\ Clementina N. Iloh \\ Federal College of Education \\ Obudu, Cross River State, Nigeria
}

\section{Doi:10.5901/jesr.2013.v3n9p87}

\begin{abstract}
This essay discusses the concepts of theatre arts and education, and the convergence of theatre arts education in national reformation. In-between cultural norms and religious values, the theatre artist as an evangelist can provide solutions to reform the declining morals and values of society. This crucial role of the theatre artist is what the author articulates and urges us to consider as an option to regain our country's lost glory. The increasing threat of social degeneration and global insecurity calls for this genre to bring about peace, unity, prosperity and development in Nigeria. The author recommends that government and stakeholders should give support and recognition to theatre arts as a profession and remind parents, teachers, community and religious leaders to restore family values. Theatre arts can crystallize action for national rebirth or re-orientation as it mirrors the society and propagates strict spiritual, moral and behavioral education to characterize child upbringing and training. Theatre arts education can influence character and moral discipline in youths and make the society a better place by stemming the tide of the growing number of delinquents who are easily enlisted and indoctrinated by terrorists, gangsters, fraudsters, kidnappers and armed robbers.
\end{abstract}

Keywords: Theatre Arts, Education, Usefulness, Reform, Nation.

\section{Introduction}

No one deserves more attention, mentoring and nurturing than our children who symbolize the bridge that connects our present with our past and even our future. It instructive and important according to Babawale(2013), to build in our youths the attributes of dialogue, reconciliation, peaceful co-existence and accommodation which characterize our culture. This is the role theatre arts education can perform creditably and remarkably when submissions, suggestions, presentations and representations by theatre arts practitioners enrich government response to the problems of moral degeneration in the society. The essential qualities of theatre arts education can preserve and promote our cultural heritage through dramatic performance of rituals, religious ceremonies and stories.

Ohiero(2005) states that in many cultures particularly in Africa there is a strong tradition of story tellers who recite myths or legends from the past, or teach moral lessons by means of stories, to a group of listeners. Most of the times, in doing this, the narrator impersonates the characters in the stories, he could sometimes change his voice to imitate the character.

Lamenting the moral quagmire in Nigeria Babawale (2013), notes that the culture of tolerance that characterizes inter-group and inter-state relationships and helps to promote societal harmony, cohesion and peaceful co-existence which was once treasured prior to our contemporary times have disappeared. One of the major factors responsible for the unruly and decadent behaviours of young people nowadays is the influence of the liberalism of the Western culture on our cultural milieu. The Western culture spoils the child by sparing the rod. It is permissive and has no firm 
control and discipline of children or teenagers. Parents and teachers should imbibe in children the virtues of love, selflessness, simplicity, humility, consideration and respect for others.

Ovbiagele (2013), holds the view that we should do away with western culture that is permissive and outrageous, and instead uphold the good values in our culture and be proud of it as we pass it on to the younger generation who are the future of our country. She states that even though the concept of democracy and freedom is meant to improve the quality of human life, if we allow the western world to make us loose what is good in our culture, we shall sink into the mire of moral decadence. To inspire values in children is having the ability to monitor the development of our children as a priority to inculcate a strong culture of respect, dignity, discipline and ethics in them.

The Woolwich, London murder of a British soldier, Mr. Lee Rigby, by two British young men, Mr. Michael Adebowale and Mr. Michael Adebolajo, of Yoruba descent, terrorist attacks, kidnappings and ritual killings in Nigeria, have done incalculable and unprecedented damage to our international image that there is urgent need to reform the country to regain its lost glory. In this exigency to transform Nigeria, theatre arts education can come to the rescue. Our customs and traditions greatly detest and abhor the spilling of human blood. Our culture inculcates compassion and aversion for horror.

Nigeria is a country with diverse, strong and rich cultural endowments which can articulate and propagate a cultural revolution to burnish our image. In this era of Boko Haram insurgency and other security challenges in the country, theatre arts education in national transformation can be used through dramatic performances to re-educate Nigerians on the core values of unity in diversity. Also respect for the sanctity of human life can be imparted. Theatre arts education in national transformation can draw attention to our values, customs and traditions as well as mirror the ills of selfish political interests and religious intolerance that are bedeviling and threatening the corporate existence of Nigeria.

\section{The Concept of Theatre Arts}

In its essence theatre arts is a collaborative form of fine arts that uses live performers to present the experience of a real or imagined event before a live audience in a specific place. The performers may communicate this experience to the audience through combinations of gesture, speech, song, music or dance. Elements of design and stagecraft are used to enhance the physicality, presence and immediacy of the experience. In other words, theatre arts is a branch of the performing arts concerned with acting out stories in front of an audience using combinations of speech, gesture, mime, puppets, music, dance, sound and spectacle, or indeed anyone or more elements of the other performing arts. Bernard Beckernan defines theatre as what "occurs when one or more human beings, isolated in time and or space, present themselves to another or others".

Performing arts education broadly includes dance, music and theatre as key elements of culture and engages the participants and public in a lifelong experience that expresses ideas and emotions to promote knowledge and understanding of the historical and cultural context of the arts. In Ohiero(2005), Oscar G. Brockett defines theatre as an art form in which series of events, usually a written play is acted out by the performers who impersonate characters. It generally takes place in an auditorium before an audience. Belt (2012), states that theatre as a concept is a means to an end. It begins as an art that develops story and character, yet it concludes with an audience's reaction. Theatre is a dramatization of reality that is perpetuated by an idea to appreciate the conceptualization that must take place for significant art to happen and serve a unique purpose to the audience. The value of art is in this ideology of theatre as a concept with a driving force behind the performance. 


\section{The Concept of Education}

We are constantly surrounded by things that educate us such as popular culture, social media, films, music and other sources of information and entertainment. Our experiences, reflections, memories and visions of life can educate us. But this presentation is going to look at some concepts of education which have to do with development and acquisition of knowledge, values and attitudes for the good and harmony in the society. These perspectives in education converge with theatre arts education for the advancement of humanity.

Nduanya (1986) cited in Ogar and Ingwu (2000) defines education as a process by which the individual is enabled to develop his capabilities through acquisition of knowledge, skills, values and attitudes both for his own benefit and for the benefit of his society. Castle (1976) in Assam ( 2012) sees education as what happens to us from the day we are born to the daywe die. While Fafunwa (1974) also cited in Assam (2012) holds that education is the aggregate as well as all the processes and other forms of behaviour which are of positive value to the society. In the same vein Ottaway(1962) also quoted in Assam (2012) maintains that education is the passing on of the cultural values and behaviour patterns of the society to its young members.

From the above definitions of education which do not quite agree with the other, the author's opinion is that education imparts knowledge, acquisition of desirable behaviour, duties of citizenship, imbibing values and ideals that lead to positive changes with the ultimate aim to make the society a better place for all of us.

\section{What Is National Reformation?}

The declining morals and values in society as a result of inadequate mentoring and supervision for our children and failure to instill core values of life into our children have done serious damage to our national psyche. This loss of values calls for national reformation and indeed, solutions to erosion of moral values and decadence. We are witnesses to increased incidence of armed robbery murder, rape, kidnappings, ritual killings, child trafficking, prostitution, fraud and production of babies for commercial and ritual purposes.

National reformation is an effort to address these social ills plaguing the country using themes in drama and theatre to bring about constructive and corrective disciplines to children as well as attitudinal change in the entire Nigerian society. The author refers to President Goodluck Jonathan's recent charge to buttress his argument. In the weekend edition of Leadership newspaper of Saturday, June 15, 2013, President Goodluck J onathan, who was represented by the Minister of Lands, Housing and Urban Development, Ms. AmaPepple, decried that Nigerians Have Lost Core Values Of Life, at the official flag-off of National Christian Campaign on Social Transformation. Its theme was Be The Change You Want To See. He declared that: "our priorities are misplaced. We have trained our children to insult elders, parents fight teachers who discipline their children and so we have been reproducing badly behaved children, who come under peers' influences. The church itself has not always done what it should do. Some of the teachings in some of our churches have turned the Bible upside down, the Bible is meant to teach us that which is right and help us to do righteous things". The president's observation is a clarion call for us to imbibe and internalize attitudinal change and breed a generation that is valued and respected.

On July 2, 2013 at the 2013 Distinguished Management Lecture organized by the Nigerian Chartered Institute of Management, held at the Nigerian Institute of International Affairs, Victoria Island, Lagos, the Speaker, House of Representatives, Hon. AminuWaziriTambuwal, who was represented by the Chairman, House Committee on Legislative Budget and Research, Hon. BamideleOpeyemi, spoke on the theme, "The Role of the Legislature on Economic, Infrastructural and Ethical Revolution in Nigeria." He emphasized that "an independent, conscientious and determined legislature" can enact laws to bring about ethical rebirth or national reformation through our cultural, economic and socio-political institutions 
Adefarasin (2013), agrees that the rot in Nigeria is deeply rooted and we must not imagine that things will change overnight or without a fight. We must commence the work to extract Nigeria from this quagmire.

\section{Comments on Transformation Agenda}

The transformation agenda of the federal government is laudable, challenging, refreshing and interesting. It captures all sectors of Nigeria without taking into consideration the arts and culture of the people. Importantly and significantly, the arts and culture of a people embrace their true nature and essence. Writing on national culture Amor (2013) affirms that arts and culture can reform our thoughts, customs and beliefs, and embrace a new sense of national identity and character thereby promoting growth and development in Nigeria. Artsin particular is more than mere craftsmanship. Arts endure through time and evolve with a people. It is therefore a serious oversight for the government transformation agenda not to include arts and culture. The Minister of Culture and Tourism should have been included in the transformation team. Theatre arts industry is also a viable economic vehicle that goes hand in hand with tourism. If the theatre is put to good use, it becomes both a source of income and a medium of communication.

The transformation agenda covers the period 2011 - 2015. The committee was formerly inaugurated on Thursday, February 11, 2011 with the under listed members:

$\begin{array}{ll}\text { Hon. Minister/Deputy Chairman, National Planning Commission } & \text { - Chairman } \\ \text { Hon. Minister of Finance } & - \text { Member } \\ \text { Hon. Minister of Transport } & - \text { Member } \\ \text { Hon. Ministerof Agriculture } & - \text { Member } \\ \text { Hon. Minister of Niger Delta Region } & - \text { Member } \\ \text { Hon. Minister of Works } & - \text { Member } \\ \text { Hon. Minister of Aviation } & - \text { Member } \\ \text { Hon. Minister of Fed. Capital Territory } & - \text { Member } \\ \text { Chief Economic Adviser to the President } & - \text { Member } \\ \text { Senior Special Assistant to the President on Infrastructure } & - \text { Member } \\ \text { Special Assistant to the President on Economic Matters } & - \text { Secretary }\end{array}$

\section{The Role of Theatre Arts Education in National Reformation}

Theatre arts preserve our culture and heritage. In other words, it is the responsibility of the theatre artist to record and preserve the age and circumstances of our folk lore, rituals, religious ceremonies and certain cultural celebrations that include elements of theatre and drama by capturing events and experiences in their theatrical performances. We are aware that apart from its huge revenue earning potentials, the theatre can be identified as a veritable platform to address the social ills plaguing the country. Therefore theatre artists can harness their resources by staging plays and producing films that portray moral rectitude, patriotism, equality and protection of children's rights. The Euro monitor reports that Nigeria's film industry is helping to change the image of Nigeria by highlighting its culture, norms, creativity and hospitality to the world.

Jaiyesinmi (2013), states that in the past few years, however, the theatre is gradually regaining its glitz and visibility. She says what makes theatre unique when compared to the other forms of arts, is not only the interaction and exchange that take place between the cast and the audience, it is also about its ability to mirror, communicate with and mould its audience. Roster and Blau cited in Jaiyesinmi (2013) hold the view that theatre arts are not merely a commodity. Essentially used as a communication, it is an important factor in the maintenance of society. George Lipsitz also quoted in J aiyesinmi (2013) states that theatre exists as training ground for life, as an activity that cultivates the ability to recognize significant communication so that the right decisions will be made. Jaiyesinmi (2013) affirms that the theatre artist is usually an evangelist of a 
sort as he wields tremendous power of using theatre's unique characteristics to impact on the mindset of the audience. Oscar Wilde in Jaiyesinmi (2013) corroborates her view and regards the theatre as the greatest of all art forms, the most immediate way in which a human being can share with another the sense of what it is to be a human being.

Mrs. Ayo Jaiyesinmi's repertoire has five themes/messages- community and citizenship, unity and diversity, culture and heritage, character and values, and family and fun.

\subsection{Plays of Renowned African Playwrights}

1. Twefik A'l Hakim: The plays of one of Egypt's foremost playwrights, dramatists and literally icons who was born on October 9, 1898 and died on July 26, 1987, encapsulate themes of national consciousness, dedication to social progress, power, eradication of injustice, corruption, among others. One of his most notable plays is Fate of a Cockroach.

2. Professor Wole Soyinka:Soyinka deploys his works of creative imagination in fighting bad governance, wastage, unreason, denial of justice, liberty, equality and equity. His Bacchae of Euripides depicts ancient culture and pulses while Death and The King's Horseman portrays the richness of his own culture to the world. A Dance in the Forest represents the misplaced priorities of African leaders as Madmen and their Specialists expose African despots and constitutional dictators who run and ruin the continent as they plunder the people's commonwealth.

3. Professor Musa Dada Enna:His latest play titled Banquet of Treachery, captures social vices such as lack of maintenance culture, inefficiency in public service, obsession for power, nepotism, sectional interest, corruption, bootlicking and lip service. He re-enacts dangerous horse-trading and dirty politicking going on in tertiary institutions whose members often criticize government policies. The goings-on in institutions of higher learning have caused crises that disrupted academic calendars and programmes.

4. Story Telling: This is an aspect of theatre arts education used to teach moral lessons and share our culture with other people. Igberaese (2013) posits that the story teller cannot cure the sick, feed the hungry or house the homeless; yet he has the capacity to communicate effectively to bring about the desired change for a better tomorrow. She explains that storytelling also helps people across cultures to travel to distant places in their mind's eyes, thereby bridging gaps, promoting understanding of other people's lifestyle. She states that Nigerian children can be mentored and nurtured through their creative ability: "we want our children to preserve Nigeria's history through our unique cultural dances, plays and songs and a whole lot. It is also to make them understand that we have a culture to be proud of and to know that they have culture to fall back on. We also want them to present the country's history through arts, plays, and dance and with whatever they do to make it easier for them. The children learn quickly by acting and role playing."

Theatre plays a major role in modeling society and securing the future of our dynamic society. This is where the government and private sector can help to develop children's skills in the arts. Learning and interaction among youths can be encouraged as well public speaking for them to express themselves. Aig-Imoukhuede (2013) emphasizes this point: "we don't want our children to stumble, so we have to prepare them for the future and it is through this medium."

What we can glean from the discussion so far is that as theatre arts plays its role to reform Nigeria, other fundamental socio-economic intervention, national policy action, legislation and civic education are needed to stay ahead of the looming crisis of loss values and social degeneration. The energies, aspirations and ambitions of young people in Nigeria should be channeled and focused away from extremism and other social vices, and directed towards our original traditional values and culture for meaning and a purpose to life. 


\section{Conclusion}

Theatre arts education in national reformation can elevate theatre practice to promote cultural, social and economic development in Nigeria. Theatre arts education in national reformation can overhaul our value systems and redeem our national ethos by distilling the elements that would internalize the values in us. This is the author's intention to enable us recognize and acknowledge the fact that theatre arts education can encourage us to live in a manner worthy of human beings so that we do not bury and waste our humanity.

\section{Recommendations}

From the foregoing discussion the following recommendation are made:

Government and stakeholders should give support and recognition to theatre arts as a profession and remind parents, teachers, community and religious leaders to restore family values. Theatre arts can crystallize action for national re-birth or re-orientation as it mirrors the society and propagates strict spiritual, moral and behavioral education to characterize child upbringing and training. Theatre arts education can influence character and moral discipline in youths and make the society a better place by stemming the tide of the growing number of delinquents who are easily enlisted and indoctrinated by terrorists, gangsters, fraudsters, kidnappers and armed robbers.

The government should design and implement a theatre arts policy to educate and enlighten Nigerians on their cultural norms, values and ethics to reform the nation. The government should consider the welfare of the people who look to it full of hope and expectations.

\section{References}

Assam, Assam Obi (ed) (2013) Introduction to the Philosophy of Education, Cross River State: Joe-Best Printers and Publications.

Ogar, N. and Ingwu, E. U. (ed) (2007) Principles and Methods of Teaching: A Text and Reader, Calabar: Index Educational Foundation and Publishers.

Ohiero, Agu (2005) Theatre and Drama in Education, Ilorin: Dele-Mighty Nig. Enterprises.

White Iheagwam, A. (2008) Philosophy and the Praxis of Education, Enugu: Theo Publishers.

Theatre as Concept: The Value of Art. http://www.cityu.org/ : Retrieved on July, 2013.

Theatre Artist Are Evangelists. http://www.cityu.org/ : Retrieved on July, 2013.

We have lost our core values of life: Leadership Weekend. J une 15, 2013. No.385. P. 7

Curbing Insecurity: Role of Culture. Nigerian Compass. Friday, June 17, 2013. P. 48

Day of drama as young sters enact stories on Nigeria: Nigerian Compass, Friday, J une 7, 2013. Vol.5 No. 1811 P. 35

Branding Nigeria for Cultural Revolution: National Mirror, Wed. July 3, 2013. Vol. 3 No. 656. P.23

Soyinka and the Awolowo prize: Nigerian Tribune, Wed. 6 March, 2013. No. 15 669. P. $1 \& 17$

A theatre scholar's spotlight on Nigeria's anti-social vices: Nigerian Tribune, Thursday 7 March, 2013. No. 15, 670. P. 26

Woolwich murder. In-between religious and cultural clash: Nigerian Tribune, Tue., 4 J une, 2013. No. 15, 733. P. 18.

Theatre will address Nigeria's social ills: Nigerian Tribune, Monday, 10 J une, 2013. No. 15737. P. 46

The Church as catalyst for national reform: Sunday Vanguard, July 14, 2013. Vol. 24 No. 10691089. P. 51 Standing firmly by the good in our culture: Sunday Vanguard, July 7, 2013. Vol. 24 No. 10691088. P.20. We need revolution now: Daily Sun, Wed. 3, 2013. Vol. 10 No. 2660. P. 5.

What is our national culture or identity? : Daily Independent, Monday 14, June, 2013. Vol. 12 No.222391. P. 33 